LETTER TO THE EDITOR

\title{
NATIONAL REGISTRY OF CONGENITAL ANOMALIES \\ OF THE CZECH REPUBLIC: COMMEMORATING 50 YEARS OF THE OFFICIAL REGISTRATION
}

\author{
Antonín Šípek ${ }^{1,2,3}$, Vladimír Gregor ${ }^{1,2}$, Jiří Horáček ${ }^{1,4}$, Antonín Šípek $\mathrm{Jr}^{1,5}$ \\ 'Department of Medical Genetics, Thomayer Hospital, Prague, Czech Republic \\ ${ }^{2}$ Department of Medical Genetics, Pronatal Sanatorium, Prague, Czech Republic \\ ${ }^{3}$ Department of General Biology and Genetics, 3rd Faculty of Medicine, Charles University, Prague, Czech Republic \\ ${ }^{4}$ Gennet, Centre for Foetal Medicine and Reproductive Genetics, Prague, Czech Republic \\ ${ }^{5}$ Institute of Medical Biology and Genetics, 1st Faculty of Medicine, Charles University and General University Hospital, Prague, Czech Republic
}

Key words: congenital anomalies, surveillance, teratogens, ICBDSR, EUROCAT, rare diseases

Address for correspondence: A. Šípek, Department of Medical Genetics, Thomayer Hospital, Vídeňská 800, 14059 Prague, Czech Republic. E-mail: registrvvv@vrozene-vady.cz

While the congenital anomalies were well known to people even in the ancient times, the teratology itself is a quite new branch of medical science. Various congenital anomalies outbreaks including the epidemics of German measles in the world in the early $1950 \mathrm{~s}$ and the thalidomide tragedy in the late 50 s and early $60 \mathrm{~s}$ of the last century lead to an improvement of our understanding of the basics of teratology. These outbreaks also showed the poor awareness on the epidemiology of various diagnoses of congenital anomalies and syndromes (1).

The local health authorities or even local hospitals in different countries responded by setting up a special monitoring systems to register cases of selected congenital anomalies and to analyze their incidences in order to intercept any new outbreak of congenital anomalies much quicker than in the case of thalidomide affair (2).

The National Registry of Congenital Anomalies (NRCA) of the (former) Czechoslovak Republic started the regular monitoring of congenital anomalies on the 1st January 1964. The official registration followed up the three years long era of unofficial registration process that was set up by MD Jiri Kucera in Prague. The continual monitoring in the Czech Republic therefore lasts for half a century this year (3).

The Decree No. 14/2001 of the Ministry of Health of the Czech Republic made the registration process compulsory. According to this law, all diagnoses included in XII. Chapter of the 10th revision of the International Classification of Diseases (ICD-10) are reported:

- in live-births and children up to the 15 th year of age;

- in stillbirths, spontaneous abortions and early foetal deaths;

- in prenatally diagnosed cases.

Stillbirth definition: non-viable foetuses, weighting more than 500 grams and older than 22 weeks. Early foetal deaths/ spontaneous abortions definition: foetuses showing no signs of life weighting less than 500 grams and younger than 22 weeks (4).

The case of congenital anomaly is reported by the specialist who diagnosed the specific condition. Most of reports are received from the neonatology departments, delivery units, paediatric de- partments and departments of medical genetics. The report is done using the official paper forms, which are centralized in the Institute of Health Information and Statistics of the Czech Republic.

More complete data on prenatal diagnostics in general and prenatally diagnosed cases of congenital anomalies are acquired upon targeted data request to all providers of prenatal genetic care (including departments of medical genetics, departments of foetal medicine, ultrasound diagnostic centres and genetic laboratories) $(4,5)$.

NRCA is an active member of the two most important international organizations dealing with surveillance of the congenital anomalies - The International Clearinghouse for Birth Defects Surveillance and Research (ICBDSR) and European Concerted Action on Congenital Anomalies and Twins (EUROCAT). NRCA was the founding member of the ICBDSR organization in 1974 (back then called ICBDMS - the International Clearinghouse for Birth Defects Monitoring Systems) (2) and has been a full member until today. In the EUROCAT organization NRCA attained associated membership in 2008 (6).

During 50 years of its existence, NRCA provided information on congenital anomalies surveillance in the Czech (Czechoslovak) Republic on the regional, national and international level. The regular reports from the NRCA data are presented in the national annual reports (available online on the website of the National Institute of Health Information and Statistics http://www.uzis.cz/) and NRCA website (http://www.vrozene-vady.cz/). Selected data are also available in the ICBDSR annual report (http://www.icbdsr. org/) and EUROCAT website (http://www.eurocat-network.eu/) (5).

The new challenges for the 21 st century include the involvement of NRCA in the primary prevention of congenital anomalies and joint action on rare diseases. Selected members of NRCA have already been involved in the creation of various primary prevention recommendations (http://www.slg.cz/primarni-prevencevrozenych-vyvojovych-vad) (7).

\section{Conflict of Interest}

None declared 


\section{REFERENCES}

1. Kalter H. Teratology in the 20th century: environmental causes of congenital malformations in humans and how they were established. Neurotoxicol Teratol. 2003 Mar-Apr;25(2):131-282.

2. International Clearinghouse for Birth Defects Monitoring Systems. Congenital malformations worldwide: a report from the International Clearinghouse for Birth Defects Monitoring Systems. Amsterdam: Elsevier; 1991.

3. Kučera J. Population teratology. Prague: Avicenum; 1989. (In Czech.)

4. Institute of Health Information and Statistics of the Czech Republic. Congenital anomalies in births in year 2011. Prague: Institute of Health Information and Statistics of the Czech Republic; 2013.
5. Šípek A, Gregor V, Horáček J, Mazanková V, Langhammer P, Šípek A Jr. History and present of registration of congenital anomalies in the Czech Republic. Cas Lek Cesk. 2009;148(10):505-9. (In Czech.)

6. Greenlees R, Neville A, Addor MC, Amar E, Arriola L, Bakker M, et al. Paper 6: EUROCAT member registries: organization and activities. Birth Defects Res A Clin Mol Teratol. 2011 Mar;91 Suppl 1:S51-S100.

7. Šípek A Jr, Šípek A, Gregor V, Macek M Jr. Primary prevention of congenital anomalies. Prakt Lek 2012;92(9):491-3. ( In Czech.)

Received November 4, 2014 Accepted in revised form November 24, 2014 